University of Nebraska - Lincoln

DigitalCommons@University of Nebraska - Lincoln

Biological Systems Engineering: Papers and

Publications

Biological Systems Engineering

9-30-2011

\title{
Stage-dependent transient storage of phosphorus in alluvial floodplains
}

\author{
Derek M. Heeren \\ University of Nebraska-Lincoln, derek.heeren@unl.edu \\ Garey A. Fox \\ Oklahoma State University, gafox2@ncsu.edu \\ Ronald B. Miller \\ Oklahoma State University \\ Daniel E. Storm \\ Oklahoma State University \\ Amanda K. Fox \\ Mathematical Services \\ See next page for additional authors
}

Follow this and additional works at: https://digitalcommons.unl.edu/biosysengfacpub

Part of the Bioresource and Agricultural Engineering Commons, Environmental Engineering Commons, and the Other Civil and Environmental Engineering Commons

Heeren, Derek M.; Fox, Garey A.; Miller, Ronald B.; Storm, Daniel E.; Fox, Amanda K.; Penn, Chad J.; Halihan, Todd; and Mittelstet, Aaron R., "Stage-dependent transient storage of phosphorus in alluvial floodplains" (2011). Biological Systems Engineering: Papers and Publications. 313.

https://digitalcommons.unl.edu/biosysengfacpub/313

This Article is brought to you for free and open access by the Biological Systems Engineering at DigitalCommons@University of Nebraska - Lincoln. It has been accepted for inclusion in Biological Systems Engineering: Papers and Publications by an authorized administrator of DigitalCommons@University of Nebraska Lincoln. 


\section{Authors}

Derek M. Heeren, Garey A. Fox, Ronald B. Miller, Daniel E. Storm, Amanda K. Fox, Chad J. Penn, Todd Halihan, and Aaron R. Mittelstet 


\title{
Stage-dependent transient storage of phosphorus in alluvial floodplains
}

\author{
Derek M. Heeren, ${ }^{1}$ Garey A. Fox ${ }^{1}$ Ronald B. Miller, ${ }^{1}$ Daniel E. Storm, ${ }^{1}$ \\ Amanda K. Fox, ${ }^{2}$ Chad J. Penn, ${ }^{3}$ Todd Halihan, ${ }^{4}$ and Aaron R. Mittelstet ${ }^{1}$ \\ 1. Oklahoma State University, Department of Biosystems and Agricultural Engineering, Stillwater, OK, USA \\ 2. Private Consultant, Mathematical Services, Stillwater, OK, USA \\ 3. Oklahoma State University, Department of Plant and Soil Science, Stillwater, OK, USA \\ 4. Oklahoma State University, Department of Geology, Stillwater, OK, USA \\ Corresponding author - Garey A. Fox, Oklahoma State University, Department of Biosystems and Agricultural Engineering, \\ Stillwater, OK 74078. USA; garey.fox@okstate.edu
}

\begin{abstract}
Models for contaminant transport in streams commonly idealize transient storage as a well mixed but immobile system. These transient storage models capture rapid (near-stream) hyporheic storage and transport, but do not account for large-scale, stagedependent interaction with the alluvial aquifer. The objective of this research was to document transient storage of phosphorus $(\mathrm{P})$ in coarse gravel alluvium potentially influenced by large-scale, stage-dependent preferential flow pathways (PFPs). Long-term monitoring was performed at floodplain sites adjacent to the Barren Fork Creek and Honey Creek in northeastern Oklahoma. Based on results from subsurface electrical resistivity mapping which was correlated to hydraulic conductivity data, observation wells were installed both in higher hydraulic conductivity and lower hydraulic conductivity subsoils. Water levels in the wells were monitored over time, and water samples were obtained from the observation wells and the stream to document $P$ concentrations at multiple times during high flow events. Contour plots indicating direction of flow were developed using water table elevation data. Contour plots of total P concentrations showed the alluvial aquifer acting as a transient storage zone, with P-laden stream water heterogeneously entering the aquifer during the passage of a storm pulse, and subsequently re-entering the stream during baseflow conditions. Some groundwater in the alluvial floodplains had total P concentrations that mirrored the streams' total P concentrations. A detailed analysis of $\mathrm{P}$ forms indicated that particulate $\mathrm{P}$ (i.e. $\mathrm{P}$ attached to particulates greater than 0.45 $\mu \mathrm{m})$ was a significant portion of the P transport. This research suggests the need for more controlled studies on stage-dependent transient storage in alluvial systems.
\end{abstract}

Keywords: alluvial floodplains, phosphorus, preferential flow, subsurface transport, transient storage

\section{Introduction}

Increased nutrient loads have resulted in several adverse impacts on surface water quality, including excessive algal growth, fish kills, and taste and odor issues across the United States and especially in the Illinois River basin in northeastern Oklahoma (Andrews et al., 2009). Nitrogen is a concern, but phosphorus $(\mathrm{P})$ is generally considered the limiting nutrient in most surface water systems (Daniel et al., 1998). Scientists and engineers need to identify critical nutrient source areas and transport mechanisms within a catchment in order to protect and enhance drinking water systems, recreation activities, and aquatic ecosystems. Subsurface contaminant transport may be important in highly conductive soils (Lacas et al., 2005), even for a highly sorbing contaminant such as P (Turner and Haygarth, 2000; Fuchs et al., 2009).

Although numerous studies have documented subsurface $\mathrm{P}$ transport from agricultural fields with tile drainage (Sims et al., 1998; Turner and Haygarth, 2000; Djodjic et al., 2004; Kleinman et al., 2004; Nelson et al., 2005; Hively et al., 2006), limited subsurface P trans- port studies have been conducted in other hydrologic settings and the transport mechanisms are generally less understood compared to transport by surface runoff (Gachter et al., 1998; Stamm et al., 1998; Heathwaite and Dils, 2000). From research on four grassland soils, Turner and Haygarth (2000) documented that subsurface $\mathrm{P}$ transport, primarily in the dissolved form, can occur at concentrations that could cause eutrophication. When assessing long-term risk of $\mathrm{P}$ loss from wasteamended soils, Nelson et al. (2005) indicated that P leaching and subsurface transport should be considered. In addition, other researchers have emphasized the importance of colloidal transport for P movement (Broberg and Persson, 1988), as P adsorbs to small particles capable of being transported through soil pore spaces in the subsurface (Haygarth et al., 1997; Addiscott et al., 2000; de Jonge et al., 2004; Fuchs et al., 2009).

There have been a few studies conducted in which observation wells were used to monitor the movement of nutrients in alluvial floodplains (Vanek, 1993; Cooper et al., 1995; Carlyle and Hill, 2001; Fuchs et al., 2009; Thompson and McFarland, 2010). Studies have shown 
high $\mathrm{P}$ availability for groundwater transport due to saturation of the riparian zone (Cooper et al., 1995) and near-streambank sediment (Thompson et al., 2010). Monitoring 12 wells in a lake riparian zone, Vanek (1993) noted groundwater $\mathrm{P}$ concentrations ranging from 0.4 to $11 \mathrm{mg} / 1$ with an average of $2.6 \mathrm{mg} / 1$. Carlyle and Hill (2001) monitored the behavior of $\mathrm{P}$ in the subsurface in a river riparian zone and suggested that riparian areas can become saturated with $\mathrm{P}$. They documented higher soluble reactive P (SRP) concentrations $(0.10$ to $0.95 \mathrm{mg} / \mathrm{l})$ in areas having soils with higher hydraulic conductivities buried under topsoils. Exchange of water and $\mathrm{P}$ between the stream and gravel subsoils is distributed across the entire river channel but enhanced in preferential pathways (Malard et al., 2002). There is a need for additional studies devoted to understanding both groundwater flow patterns and P transport through the subsurface of alluvial floodplains.

One approach for simulating contaminant transport during the interaction between streams and alluvial aquifers is through a transient storage zone model, with the transient storage zone commonly idealized as a well mixed but immobile system (Bencala and Walters, 1983). Harvey et al. (1996) suggested that this idealization captures rapid hyporheic storage and transport (i.e. near-streambed exchange) but cannot capture exchange with the more extensive alluvium. Changes in discharge and stream stage are suggested to influence near-streambed transient storage ( $\mathrm{D}^{\prime}$ Angelo et al., 1993; Morrice et al., 1997; Hart et al., 1999; Worman et al., 2002; Zarnetske et al., 2007; Stofleth et al., 2008). However, as noted by Zarnestke et al. (2007), ' ... the overall understanding of how they (perturbations in discharge, elevation of channel stage, and water table) correlate to in-channel and hyporheic storage dynamics is still unclear ...', especially for larger-scale interactions with the alluvium. The presence of large-scale transient storage at high-stream stages may have a direct impact on the transport of in-stream contaminant loads as the stream water interacts with the alluvial groundwater in floodplains throughout the watershed.

It is well known that paleochannels, or linear deposits of coarse-grained sediments, exist across floodplains and link modern channel flows to distal floodplain areas (Stanford and Ward, 1992; Poole et al., 1997; Amoros and Bornette, 2002; Naiman et al., 2005). Hydrologic pathways become complex with deposits of coarse alluvium (Naiman et al., 2005). Poole et al. (2002) characterized a coarse alluvial aquifer on the Middle Fork Flathead River in Montana, with a localized hydraulic conductivity on the order of $10000 \mathrm{~m} / \mathrm{d}$. Preferential flow paths (PFPs) were identified with $20 \%$ of the river's flow entering the aquifer in one area and reemerging downstream. Also, paleochannels in the vadose may become active once the stream stage has reached a specific elevation to transmit flow. Preferential flow through paleochannels would result in complex, largerscale flow patterns that would be considered beyond the scale and definition of hyporheic zone flow. However, limited data has been reported on $\mathrm{P}$ transport through these floodplain-scale PFPs.

Large-scale preferential flow and transient storage become more significant in streams adjacent to highly conductive alluvial aquifers. For example, the Ozark ecoregion of Missouri, Arkansas, and Oklahoma is approximately $62,000 \mathrm{~km}^{2}$ and is characterized by gravel bed streams that have migrated substantially over time yielding many paleochannels throughout the ecoregion. The erosion of carbonate bedrock (primarily limestone) by slightly acidic water has left a large residuum of chert gravel in Ozark soils, with floodplains generally consisting of coarse chert gravel overlain by a mantle $(1-300 \mathrm{~cm})$ of gravelly loam or silt loam. The same processes have resulted in karst topography, including caves, springs, sink holes, and losing streams (Neill et al., 2003; Davis et al., 2005).

The objective of this research was to document largescale, stage-dependent transient storage of $\mathrm{P}$ in coarse alluvial aquifers potentially influenced by PFPs. An extensive body of literature exists for near-stream transient storage but only limited data has been published on larger-scale transient storage. In this research, transient storage includes storage in both perpetually and variably saturated substrates, the latter of which is often referred to as bank storage. While the long-term monitoring was performed in the Ozark ecoregion, similar hydrogeologic conditions exist in gravel bed streams and their associated shallow alluvial aquifers worldwide.

\section{Methods and Materials}

\section{Alluvial floodplain sites}

The alluvial floodplain sites were located in the Ozark ecoregion of northeastern Oklahoma. The Barren Fork Creek site (Figure 1(a), latitude: $35.90^{\circ}$, longitude: $-94.85^{\circ}$ ) was immediately downstream of the Eldon Bridge U.S. Geological Survey (USGS) gage station 07 197 000. With a watershed size of $845 \mathrm{~km}^{2}$, the Barren Fork Creek site was a fourth-order stream with a historical median discharge of $3.6 \mathrm{~m}^{3} \mathrm{~s}^{-1}$. The study area at the Barren Fork Creek was located on the outside of a meander bend which was being actively eroded by the stream. The Honey Creek site (Figure 1(b), latitude: $36.54^{\circ}$, longitude: $-94.70^{\circ}$ ) was also located immediately downstream of a USGS gage station (07 189 542). As a third-order stream, the Honey Creek site had a $0.54 \mathrm{~m}^{3} \mathrm{~s}^{-1}$ historical median discharge and a $150 \mathrm{~km}^{2}$ watershed. The riparian area on Honey Creek was located on the inside of a meander bend, an area likely to be aggradational.

The Barren Fork Creek site was a hay field with a Mehlich III soil test P (STP) of $33 \mathrm{mg} / \mathrm{kg}$ in the top 15 $\mathrm{cm}$ and had not received fertilizer for several years. The Honey Creek study site was composed of both forest and grassland. Adjacent to a tree farm, the area had received fertilizer in the past resulting in a current STP of $60 \mathrm{mg}$ / $\mathrm{kg}$ in the top $15 \mathrm{~cm}$. The soils of both floodplain sites 


\section{(a) Barren Fork Creek}

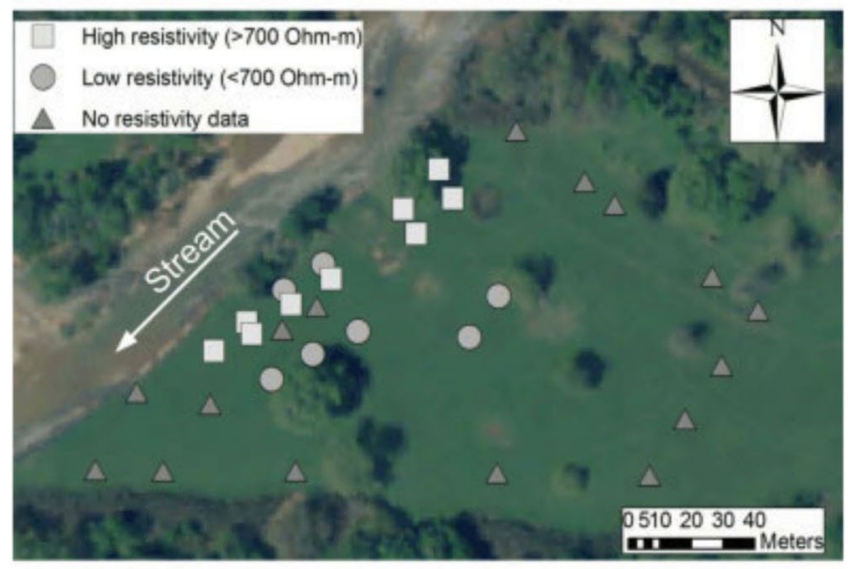

(b) Honey Creek

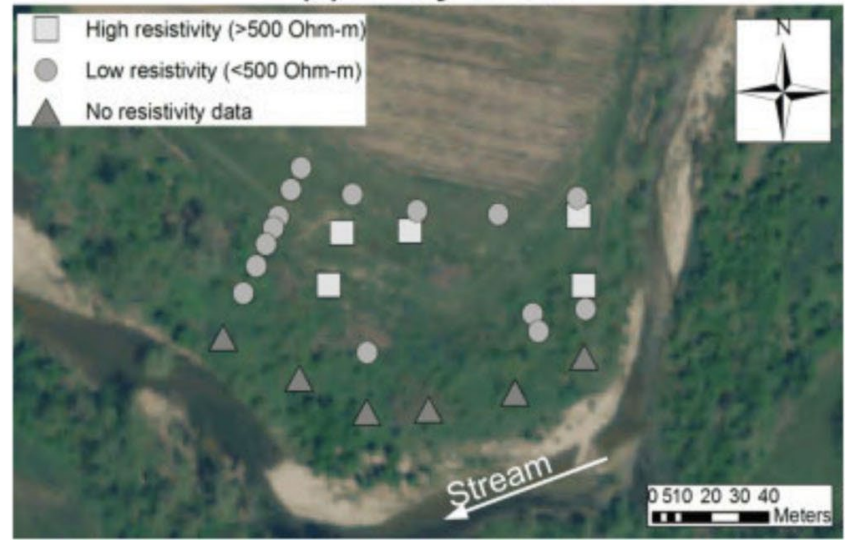

Figure I. Observation well locations overlain on aerial images (NAIP, 2008) for the Barren Fork Creek site (a) located near Tahlequah, Oklahoma, and the Honey Creek site (b) located near Grove, Oklahoma. Most wells were located based on electrical resistivity data, with high resistivity subsoils considered to have potential for preferential flow.

were classified as Razort gravelly loam underlain with alluvial gravel deposits. Thickness of the loam ranged from 0.5 to $1.0 \mathrm{~m}$ at the Barren Fork Creek site, and from 0.1 to $0.5 \mathrm{~m}$ at the Honey Creek site. Soil hydraulic studies on these soil types have shown that subtle morphological features can lead to considerable differences in soil water flow rates (Sauer and Logsdon, 2002). Fuchs et al. (2009) described some of the soil and hydraulic characteristics of the Barren Fork Creek floodplain site, including estimates of hydraulic conductivity for the gravel subsoil between 140 and $230 \mathrm{~m} \mathrm{~d}^{-1}$ based on falling head trench tests. They reported a P sorption maximum of $125 \mathrm{mg} \mathrm{kg}^{-1}$ and a binding energy of $0.048 \mathrm{l} \mathrm{mg}^{-1}$ for a Langmuir isotherm performed on the fine material (i.e. $<2.0 \mathrm{~mm}$ ) in the alluvial aquifer. The degree of $\mathrm{P}$ saturation (i.e. $\mathrm{P} /[\mathrm{Al}+\mathrm{Fe}]$ ) was found to be $4-8 \%$ based on ammonium oxalate extractions. Heeren et al. (2010) performed a tracer injection into a PFP, identified as a buried gravel bar, at the Barren Fork site. Local transient storage was observed as evidenced by the elongated tails of breakthrough curves in some observation wells due to physical heterogeneity in the aquifer materials.
Electrical resistivity mapping and observation well installation

Geophysics has been widely used for subsurface mapping (Pellerin, 2002; Robinson et al., 2008). Resistivity mapping involves measuring the electrical properties of near-surface earth materials, which vary with grain size, mineral type, solute content of pore water, and porespace saturation. Apparent electrical resistivity is calculated at several locations in a two-dimensional profile by carefully measuring the voltage generated by a known electrical current using four electrodes in contact with the soil. Miller et al. (2010) collected electrical resistivity data using a SuperSting R8/IP Earth Resistivity Meter (Advanced GeoSciences Inc., Austin, TX) with a 56-electrode array. The profiles at the Barren Fork Creek site employed electrode spacings of $0.5-2.5 \mathrm{~m}$ with associated depths of investigation ranging from 7.5 to 25.0 $\mathrm{m}$, respectively. The Honey Creek site utilized a 1-m spacing, with an associated depth of investigation of approximately $10 \mathrm{~m}$. The area of interest in each study site, which was less than $5 \mathrm{~m}$ below the ground surface, was well within the ERI depth of investigation. The resistivity sampling and subsequent inversion utilized a proprietary routine devised by Halihan et al. (2005), which produced higher-resolution images than conventional techniques. Electrical resistivity results showed subsurface heterogeneity at both floodplain sites (Figure 2). One of the high-resistivity areas at the Barren Fork Creek site matched a PFP observed in previous research (Fuchs et al., 2009; Heeren et al., 2010).

Using a borehole permeameter specifically designed for coarse gravel subsoils (Miller et al., 2011) to measure saturated hydraulic conductivity in situ, Miller et al. (2010) established a positive correlation between electrical resistivity and hydraulic conductivity for the Barren Fork Creek and Honey Creek floodplain sites. Based on that correlation and the previous electrical resistivity results (Heeren et al., 2010; Miller et al., 2010), observation wells were located in both higher electrical resistivity (possible PFP) and lower electrical resistivity subsoils (Figures 1 and 2). In this research, a PFP was defined as a zone of high hydraulic conductivity in the subsoil that has potential for rapid transport of water and solutes.

A Geoprobe Systems drilling machine (6200 TMP, Kejr, Inc., Salina, KS) was used to install observation wells in the alluvial floodplains with a $2.0-3.0 \mathrm{~m}$ screened section at the base. Depth to refusal for installed wells ranged from $4.0 \mathrm{~m}$ to greater than $5.0 \mathrm{~m}$ at the Barren Fork Creek site, and from 2.5 to $3.5 \mathrm{~m}$ at the Honey Creek site. Bentonite clay was placed at the top of the well casing to prevent surface runoff from entering the borehole. Well locations were surveyed using a TOPCON HiperLite Plus global positioning system configured with a base station and rover unit $(4 \mathrm{~cm}$ accuracy). These data were corrected for positional errors using the National Geodetic Survey Online Positioning User Service (OPUS). Since the water table elevation data were more sensitive to measurement error than 


\section{(a) Barren Fork Creek}

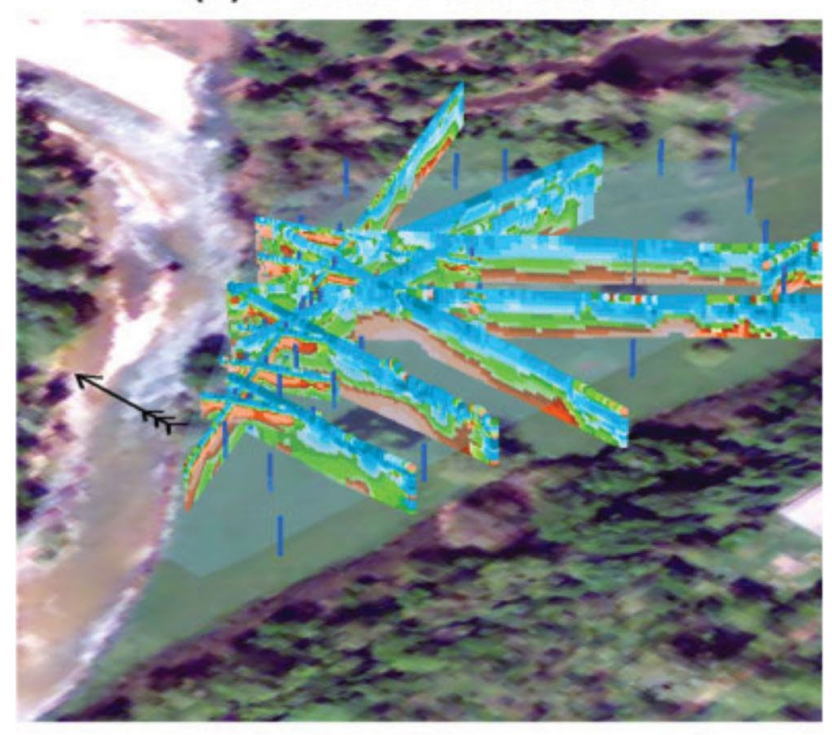

(b) Honey Creek

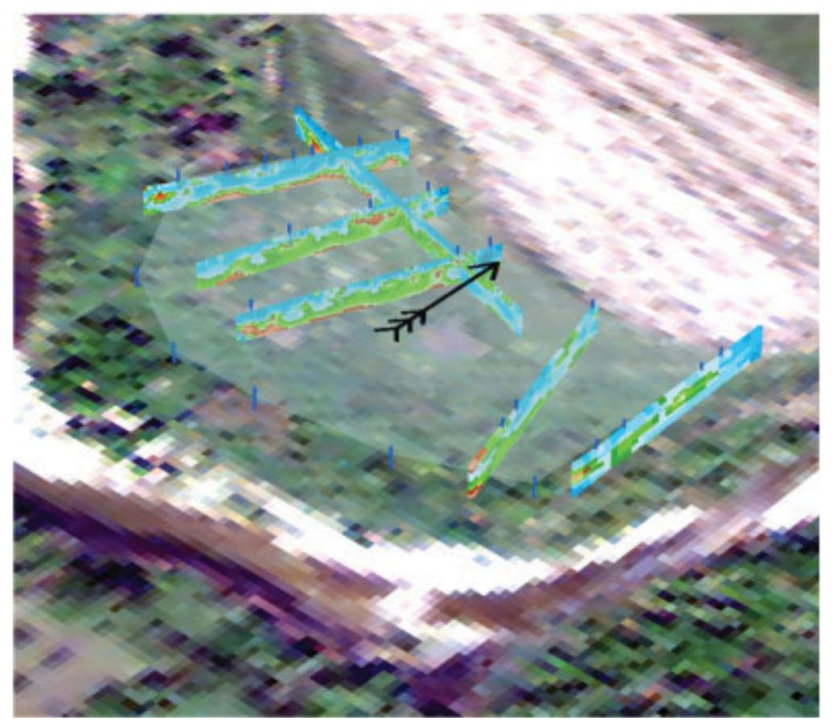

Figure 2. Barren Fork Creek (a) and Honey Creek (b) vertical (5 m) electrical resistivity profiles which have been positively correlated $\left(r^{2}\right.$ $=0.73$ ) to saturated hydraulic conductivity (Miller et al., 20l0). Blue is low resistivity (less than $375 \Omega$-m); green is medium; and orange is high (greater than $700 \Omega-m$ ). The shaded areas demarcate well fields, with blue lines indicating observation well locations. The black arrows show true north; aerial images are from NAIP, 2008.

horizontal position, a laser level was used to determine the elevation at the top of each well (1 cm accuracy).

\section{Long-term monitoring for groundwater flow patterns}

At each site, 24 observation wells were instrumented with automated water level loggers (HoboWare, Onset Computer Corp., Cape Cod, MA, water level accuracy of $0.5 \mathrm{~cm}$ ) to monitor water pressure and temperature at 5-min intervals from April 2009 to April 2010. One logger was placed above the water table at each site to account for changes in atmospheric pressure. Reference water table elevations, obtained with a water level indicator, were then calculated. The logger data were processed with HoboWare Pro software, which accounted for changes in atmospheric pressure as well as changes in water density due to temperature and produced water table elevation data ( $1 \mathrm{~cm}$ accuracy).

Water table elevation data were analyzed with Matlab (The Mathworks, Natick, MA). Using 30-min intervals, a cubic interpolation was performed to determine the head for grid points in the two-dimensional well field. Contour maps were plotted with equipotential lines using a 2-cm interval. While streamlines were not necessarily perpendicular to contour lines due to anisotropy and unsteady flow during high-flow events, the contour plots did indicate general flow patterns in the groundwater system. Patterns in groundwater contours were investigated at both baseflow conditions and during storm events. Data from the local USGS gage stations were also used in the analysis.

\section{Phosphorus sampling and testing}

Water samples from observation wells were collected during multiple high-flow events using a peristaltic pump. Samples were obtained at 7 different times (September 2009 and March 2010) from the stream, and 19-23 observation wells at the Barren Fork Creek site, and at 6 different sampling times (October 2009 and March 2010) from the stream, and 21 observation wells at the Honey Creek site (Table I, Figure 3). The number of observation wells at the Barren Fork Creek site decreased over time due to rapid streambank erosion (Midgley et al., 2011). High-flow events were of particular interest because stream P concentrations generally increase with streamflow in these watersheds (Andrews et al., 2009). While samples were collected from the top of the water table (i.e. upper $10 \mathrm{~cm}$ ) in order to avoid sediment in the bottom of the wells, water in the well was assumed mixed during pumping. Water samples were stored on ice and transported back to the laboratory for analysis. After digestions with the sulfuric acid-nitric acid method (Pote $e t$ al., 2009), total $P$ concentrations were determined colorimetrically (Murphy and Riley, 1962) with a spectrophotometer (Spectronic 21D, Milton Roy, Ivyland, PA).

Contour plots of total $\mathrm{P}$ concentration were generated with Matlab (The Mathworks, Natick, MA). A cubic interpolation was performed to determine the $\mathrm{P}$ concentration for grid points in the two-dimensional well field with a contour interval of $10 \mu \mathrm{g} / 1 \mathrm{P}$. Kriging, which attempts to express trends suggested in the underlying data (Cressie, 1991), was also considered as a geostatistical technique for interpolating the P data. Developed using Surfer 8 (Golden Software, Inc., Golden, CO), variograms were used to quantitatively assess the spatial continuity in the data, but consistent trends were not observed in the data due to the complex nature of the alluvial deposits. Also, any spatial relationships in the variograms may have been obscured by the asymmetrical distribution along with the limited number of obser- 
Table I. Hydrologic data and total phosphorus concentrations ( $\mathrm{mg} / \mathrm{l}$ as $\mathrm{P}$ ) for each sampling time. Groundwater concentrations are characterized by the median and interquartile range (IQR). Percent particulate phosphorus $(P)$ is the mean of the groundwater samples

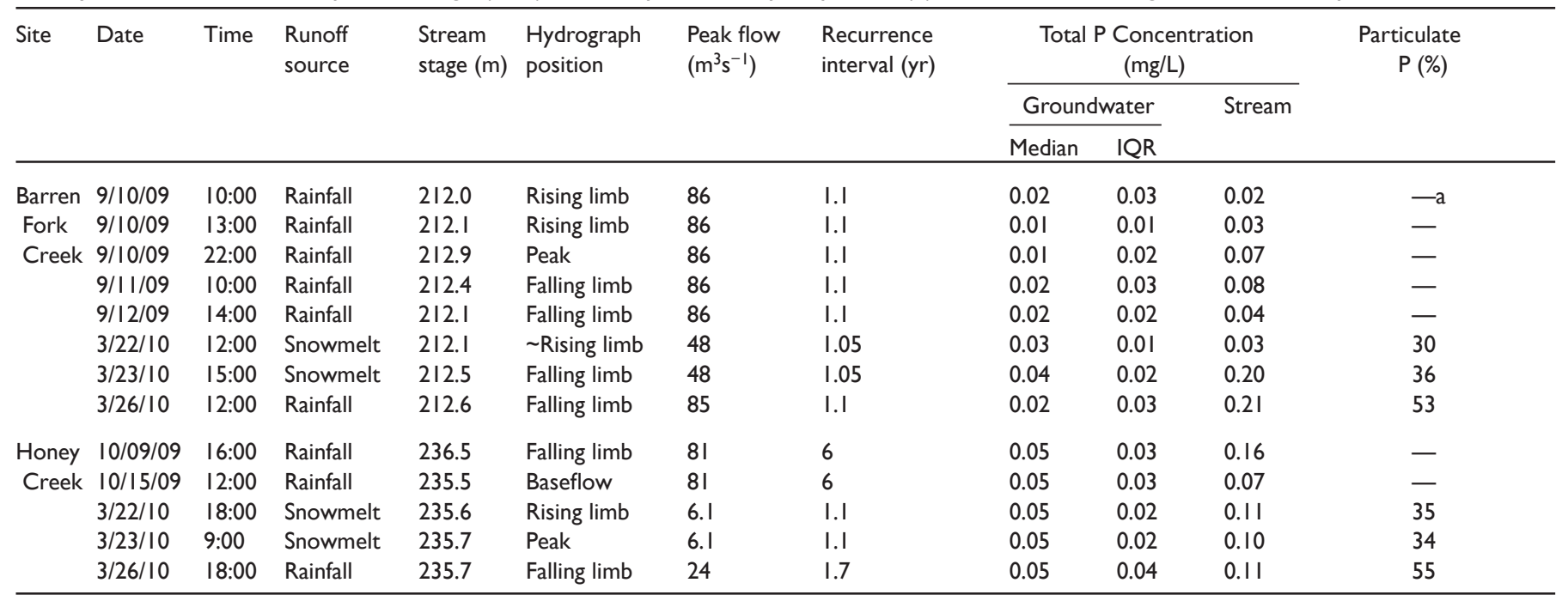

a. Not measured for 2009 samples.

vation wells. Therefore, the cubic interpolation was selected as the best visual presentation of the data.

Samples collected in 2010 were further analyzed to determine P forms. Filtration with a $0.45 \mu \mathrm{m}$ filter (Millipore mixed cellulose ester membranes, Fisher Scientific, Waltham, Mass.) was used to remove particulates greater than $0.45 \mu \mathrm{m}$. Filtered samples were tested with the spectrophotometer for dissolved reactive $\mathrm{P}$ and an Inductively Coupled Plasma-Optical Emission Spectrometer (ICP-OES, Arcos, SPECTRO Analytical Instruments, Kleve, Germany)-for total dissolved P. The minimum detection limit was $0.01 \mathrm{mg} / 1 \mathrm{P}$ for both the spectrophotometer and the ICP-OES.

\section{Results and Discussion}

\section{Groundwater flow patterns}

Patterns in the water table elevation contour plots at the Barren Fork Creek and Honey Creek field sites during the 12-month observation period remained relatively consistent during baseflow conditions, but changed during high-flow events. Plots for times at which P samples were collected, as well as two additional times to illustrate rising limb stream conditions, illustrate the range of groundwater flow patterns in the dataset (Figures $4-8$ ). The highest gradients in the alluvial aquifers occurred during the rising limbs of the hydrographs (Figures 4(a) and 7(a)), when the stream stage was rising most quickly. The average groundwater gradient after the peak (Figures 5(a) and 6(c) for the Barren Fork Creek site; Figures 7(b) and 8(b) for the Honey Creek site) shifted quickly back to the average gradient during baseflow conditions (Figures 5(c) and 7(c)).

Flow directions in the groundwater changed considerably between base and peak flows, suggesting that the floodplains acted as transient storage zones, rapidly storing and releasing water during passage of a storm pulse. At the Barren Fork Creek field site, the average direction in the floodplain was approximately southwest $\left(200-220^{\circ}\right)$ during baseflow conditions (Figure 5(c)) (i.e. away from the stream in the direction of flow), but changed to a southeastern direction (300-320 ) (i.e. away from the stream opposite of the stream flow direction) during large flow events (Figure 4(a)-(c)). At the Honey Creek floodplain site, the average groundwater direction was southwest $\left(210-220^{\circ}\right)$ (i.e. across the meander bend and directed back towards the stream) during baseflow conditions (Figure 7(c)). During storm events, the average direction changed to northwest (i.e. $130-150^{\circ}$ or away from the meander bend) (Figure 7(a)). The change in the direction at both field sites appeared to be a function of the rate of change in the stream stage, with higher rates of change correlating to greater variations in the average groundwater direction compared to the direction under baseflow conditions. The changes in average groundwater direction indicated the occurrence of transient storage within the floodplain: groundwater flow direction changed as water moved rapidly into the floodplain during the rising limb of the streamflow hydrograph and then returned to its original average direction as water drained during the recession of the hydrograph.

Besides stream-aquifer interactions, the impact of aquifer heterogeneity could also be seen in the water table contour plots. The primary source of heterogeneity was expected to be saturated hydraulic conductivity, a parameter which spans several orders of magnitude, but it is acknowledged that spatial variability in porosity and aquifer depth also contributes to non-uniform flow patterns. While streamlines were not necessarily perpendicular to contour lines due to anisotropy and unsteady flow during high-flow events, the contour plots did indicate general flow patterns in the groundwater system. 
(a) Barren Fork Creek

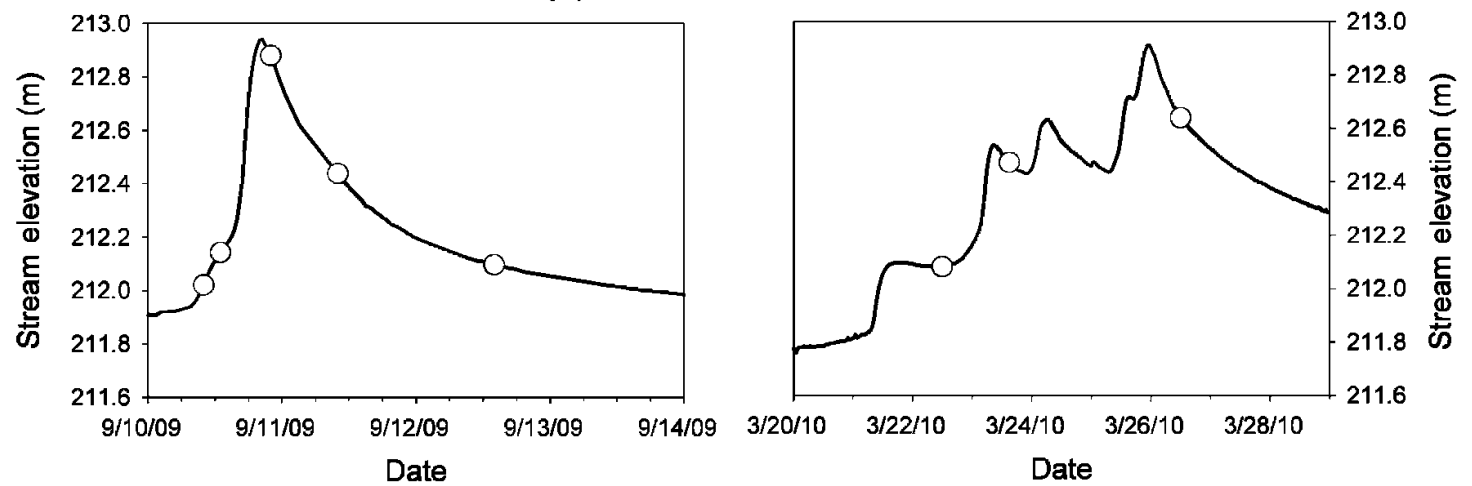

(b) Honey Creek
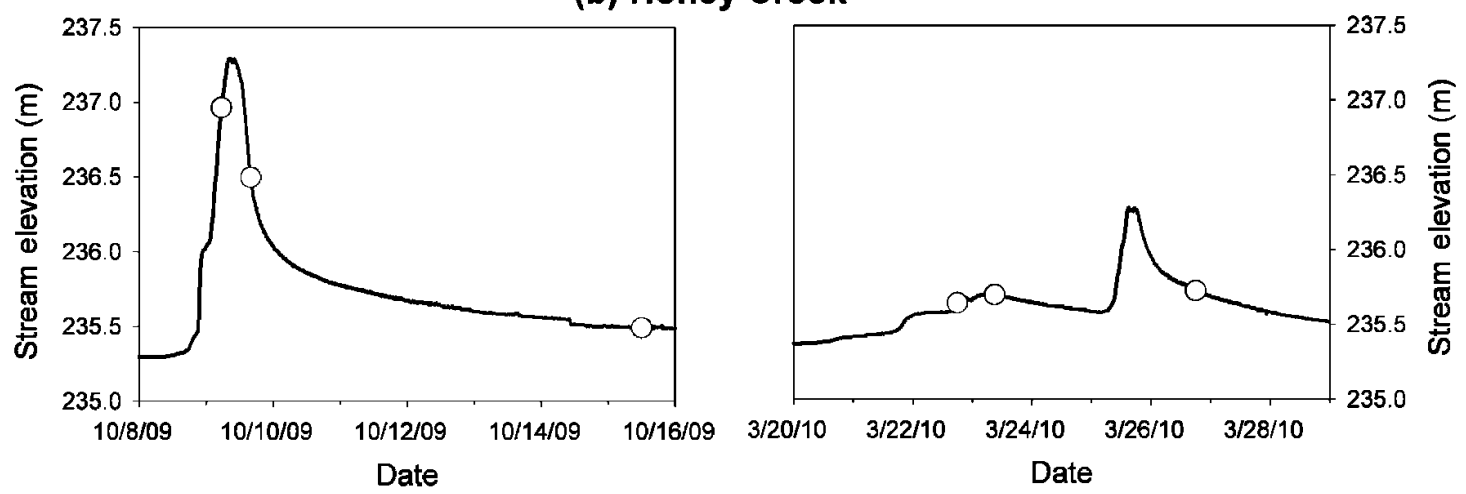

Figure 3. Hydrographs for the Barren Fork Creek (a) and Honey Creek (b) field sites based on upstream gage stations. Circles designate dates of water table contour plots and phosphorus sampling from the observation wells and streams. Note, that samples were not collected for the first point on the Honey Creek hydrograph, but the water table data was included to illustrate groundwater flow during rising limb conditions.

Flow patterns showed groundwater areas, potentially PFPs, acting as flow convergence (i.e. draining a large groundwater area) or divergence (i.e. allowing stream water to quickly enter the groundwater system) zones. For example, a zone of focused recharge can be seen along the Barren Fork Creek (Figure 4(a)) providing an inlet for stream water to enter the groundwater system. This divergence zone was at point $(80 \mathrm{~m}, 60$ m) (Figure 4(a) compared to Figure 2(a)), which is the location of the PFP investigated in previous research (Fuchs et al., 2009; Heeren et al., 2010) and was evident in the electrical resistivity datasets. While the buried gravel bar also extends to the northeast (see high resistivity wells in Figure 1(a)), the divergence zone in the flow data during rising stream stage conditions occurs where the PFP intersects the stream (Figure 4(a)). Intuitively, the highest water table elevation should be at the top-center of the contour plot $(150 \mathrm{~m} / 110$ $\mathrm{m})$, at the upgradient end of the stream; however, the highest water table elevation was in the possible PFP, where stream water could most readily enter the alluvial aquifer. This possible PFP was not visible in the contour patterns at later dates (Figures 4(b), (c) and $5(a)$ (c)) since much of the area was removed due to streambank erosion between May and September, 2009 (Midgley et al., 2011). Another divergence zone was observed at the Honey Creek site $(220 \mathrm{~m}, 120 \mathrm{~m})$ (Figure $8(\mathrm{a})$ (c)). The correlation with electrical resistivity (Figure 2(b)) was less obvious in this case.
At other times, the contour patterns indicated flow convergence zones draining a large area of groundwater. For example, at the Honey Creek site, there was a zone between points $(160 \mathrm{~m}, 125 \mathrm{~m})$ and $(210 \mathrm{~m}, 120 \mathrm{~m})$ (Figure 7(a)), which drained a large area of groundwater to the west-northwest. The location was consistent with the location of previously hypothesized PFPs based on electrical resistivity data (Miller et al., 2010), including the high contrast in electrical (and hydraulic) properties between the two wells near-point $(170 \mathrm{~m}, 125 \mathrm{~m})$ (Figure 7(a) compared to Figure 2(b)). The activity of this convergence zone depended on stream stage. That is, it was hypothesized that one or more PFPs were positioned in the vadose zone and began to rapidly transport water when the water table reached their elevation. This convergence zone became hydraulically activated sometime before the water table reached an elevation of $236.5 \mathrm{~m}$ (Figure 7(a)). It must also have been activated in Figure 7(b) (with a water table elevation of $237 \mathrm{~m}$ ) but its impact on groundwater flow patterns may have been masked due to flow being generally perpendicular to the high-conductivity zone during the falling limb of the hydrograph. Thus, the potential impact of one or more PFPs on flow was hypothesized to be a function of both stream stage and stream-aquifer interactions. The stage-dependent convergence zone at Honey Creek was more active in 2009 due to the 6-year recurrence interval event, compared to the less than 2-year recurrence interval events in 2010 (Figure 3). While the impact of 
(a)

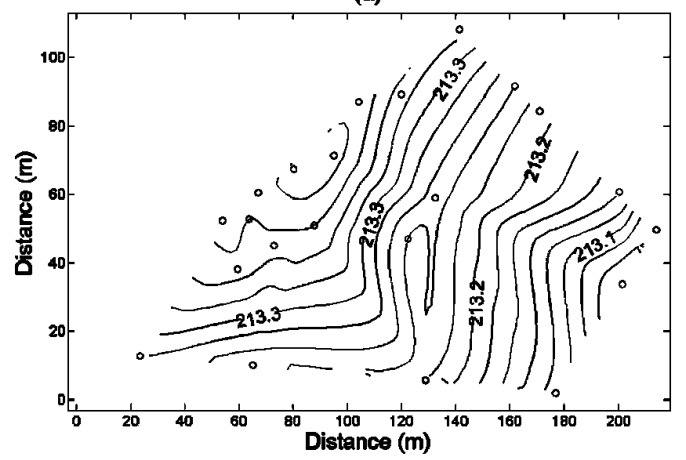

(b)

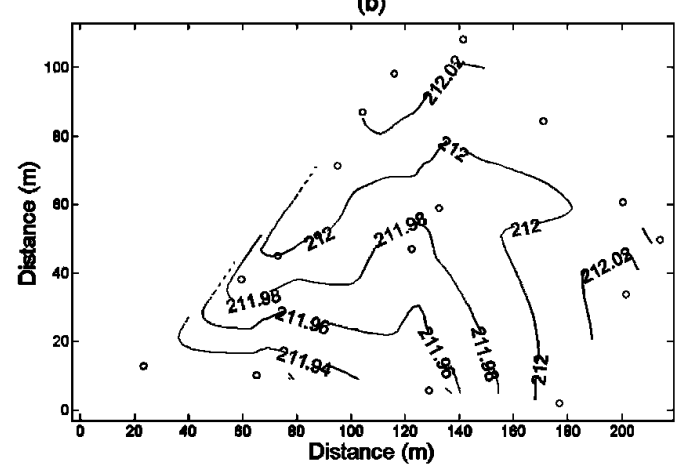

(c)
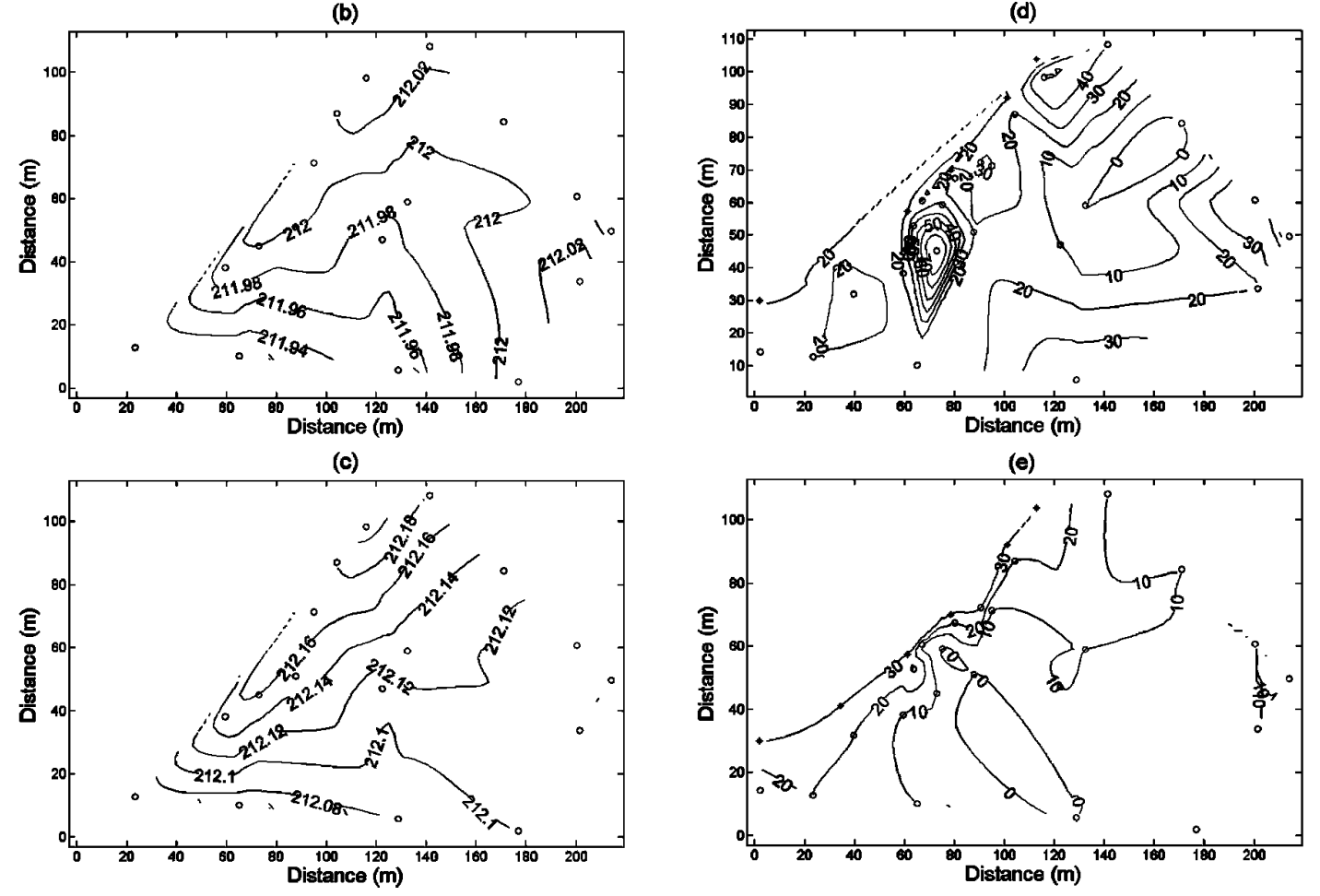

(e)

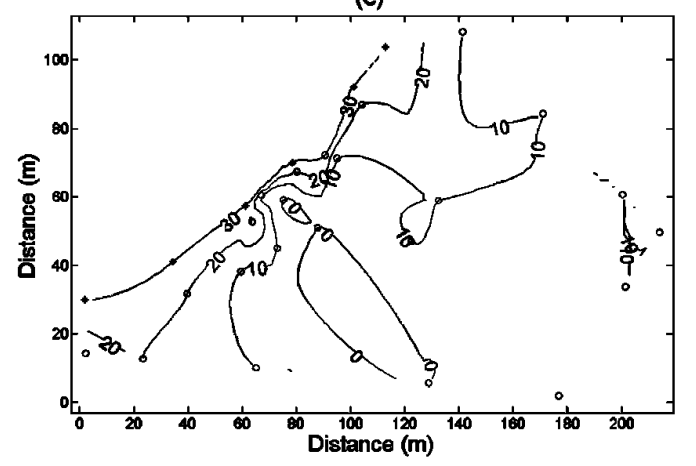

Figure 4. Water table contour plot (a) for the Barren Fork Creek site during the rising limb of May 6, 2009 high-flow event before significant streambank erosion occurred (Midgley et al., 20I I). Water table ((b) (c)) and total phosphorus ((d) (e)) concentration ( $\mu$ g/l as P) contour plots for the first ((b) (d)) and second ((c) (e)) sampling times during the rising limb of September 10, 2009 high-flow event. Interpolations are based on measured data from wells (circles) and the stream (stars). See Table I and Figure 3 for more information on hydrologic conditions at the time of sampling.

specific PFPs was difficult to quantify with this dataset, such results emphasize the stage-dependent nature of focused recharge/discharge in these systems and more work should be devoted to understanding the occurrence and activation of alluvial flow pathways.

\section{Phosphorus concentrations}

Water samples from observation wells were collected during multiple high-flow events (Figure 3) with peak flows from one to two orders of magnitude greater than median flow rates (Table I) and were subsequently analysed for total P concentrations (Figures 4-8). During baseflow conditions, groundwater $P$ concentrations were typically $0.01-0.04 \mathrm{mg} / \mathrm{l}$ and $0.02-0.06 \mathrm{mg} / \mathrm{l}$ at the Barren Fork Creek and Honey Creek field sites, respectively. Groundwater P concentrations rose during highflow events and were generally highest where stream water was entering the groundwater system and decreased with distance downgradient from the stream (Figures 5(d) (e), 6(e) (f), 7(d), and 8(d)-(f)). The decrease in $\mathrm{P}$ concentrations farther into the aquifer is likely due to sorption of the P onto the fine material in the gravel, as well as dilution with the groundwater. Even though total $\mathrm{P}$ concentrations decreased as stream water moved through the aquifer, transient storage was occurring in the alluvial aquifer as seen in the significant levels of $P$ leaving the study area (and presumably re-entering the stream). Total P concentrations of groundwater leaving the well field often exceeded $0.037 \mathrm{mg} / \mathrm{l}$, which is the standard set for Oklahoma Scenic Rivers (OWRB, 2010), which include the Barren Fork Creek (a tributary to the Illinois River).

During high-flow events, the maximum $\mathrm{P}$ concentrations measured in the groundwater were approximately a factor of 5 over background levels, reaching $0.20 \mathrm{mg} / 1$ 
(a)

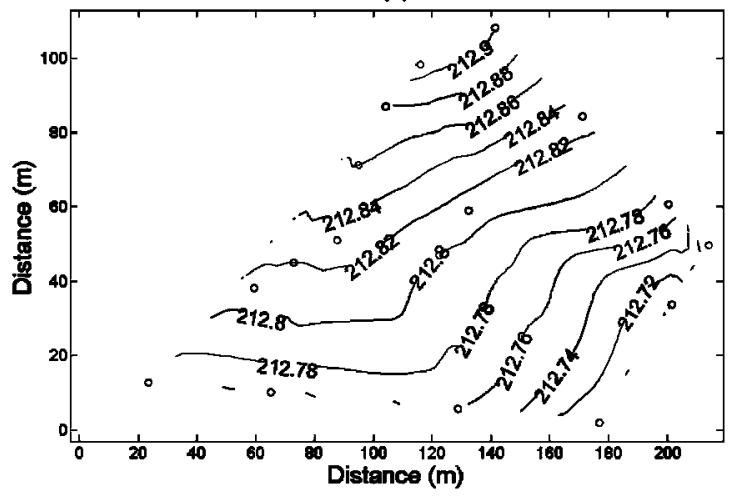

(b)

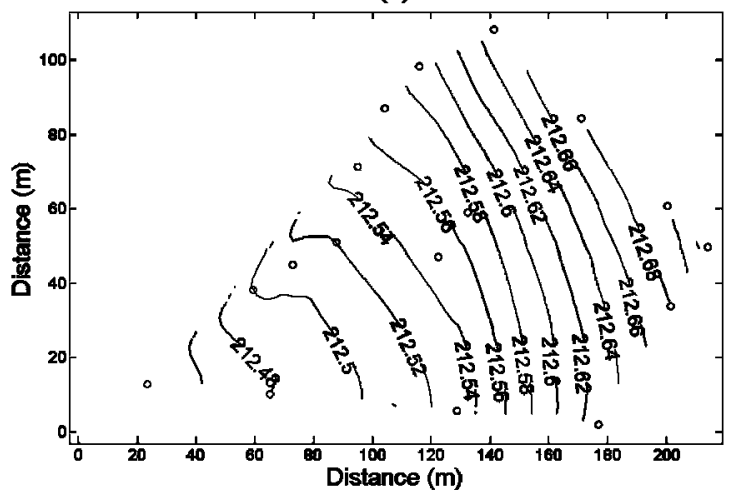

(c)

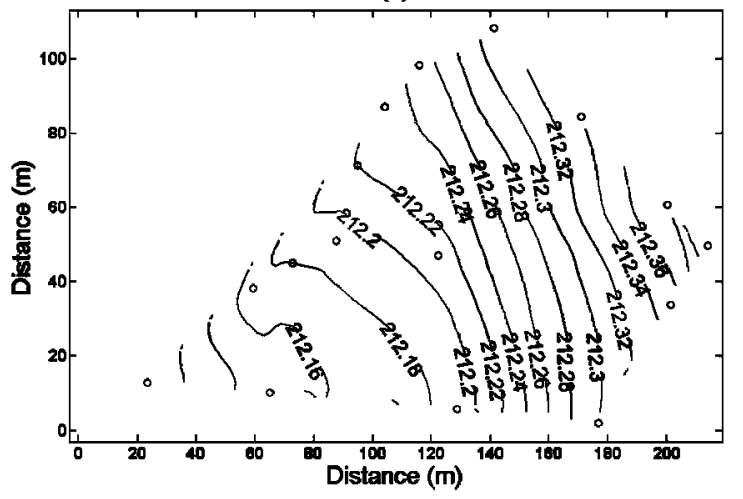

(d)

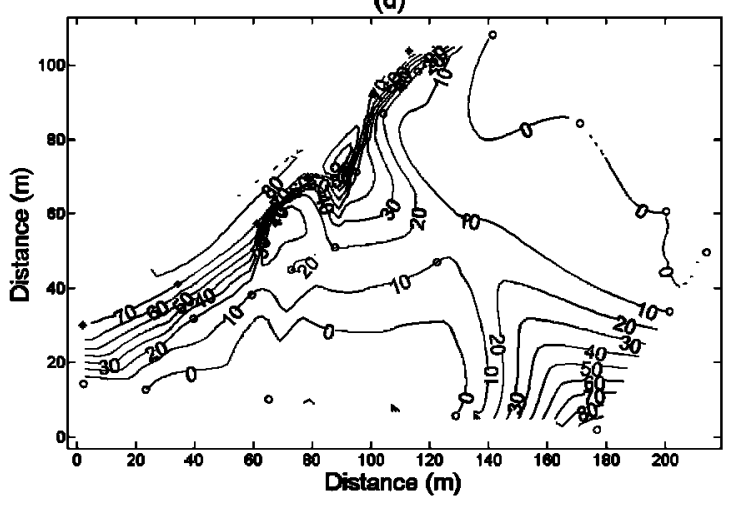

(e)

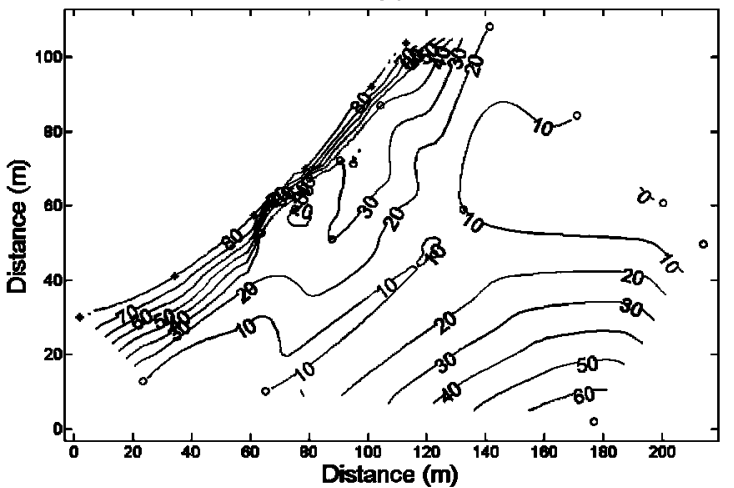

(f)

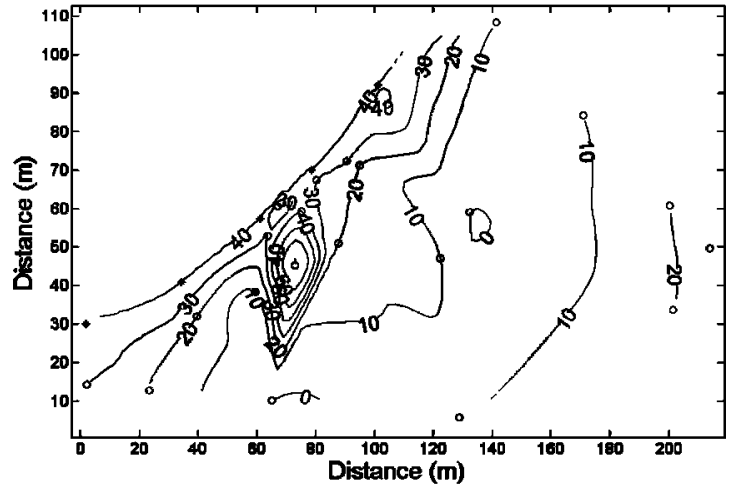

Figure 5. Water table ((a) (c)) and total phosphorus ((d) (f)) concentration ( $\mu \mathrm{g} / \mathrm{I}$ as $\mathrm{P})$ contour plots for the Barren Fork Creek site during the peak ((a) (d)) and the first ((b) (e)) and second (c) (f) sampling times of the recession limb of September 10, 2009 high-flow event. Interpolations are based on measured data from wells (circles) and the stream (stars). See Table I and Figure 3 for more information on hydrologic conditions at the time of sampling.

at the Barren Fork Creek site and $0.25 \mathrm{mg} / \mathrm{l}$ at the Honey Creek field site. Although total P concentrations generally decreased as alluvial groundwater traveled further from the stream, in some of the groundwater domain rapid transport of $\mathrm{P}$ occurred with concentrations at or near the $\mathrm{P}$ concentration in the streams during larger storm events. For example, one or more possible PFPs located at $(220 \mathrm{~m}, 120 \mathrm{~m})$ on the Honey Creek site facilitated transport of $\mathrm{P}$ into the floodplain (Figure 8(d)-(f)). At the Barren Fork Creek site, well 28 (at point $(180 \mathrm{~m}$, $0 \mathrm{~m}$ ) in Figure 5(d)(e)) was $100 \mathrm{~m}$ from the stream and had $\mathrm{P}$ concentrations similar to the stream $\mathrm{P}$ concentrations. Well 28 was located adjacent to an abandoned stream channel that runs along a bluff; it was hypothesized that a buried lateral gravel bar served as a flow and transport pathway (Heeren et al., 2010). All zones of high electrical resistivity and, therefore, high hydraulic conductivity (possible PFPs) did not always show rapid $P$ transport as these pathways must be hydraulically activated and connected to a source of $\mathrm{P}$ for preferential transport to occur. With limited spatial and temporal data throughout the saturated aquifer material, it was difficult to quantify the impact of specific PFPs on $P$ transport. However, this research demonstrates that preferential transport does occur and that it should be further investigated using three-dimensional $\mathrm{P}$ sampling in the alluvial material (Vadas et al., 2007).

Possible sources of $\mathrm{P}$ in the groundwater included stream-aquifer interaction, $\mathrm{P}$ leaching from the topsoil due to rainfall infiltration, P-laden run-on (from up- 
(a)

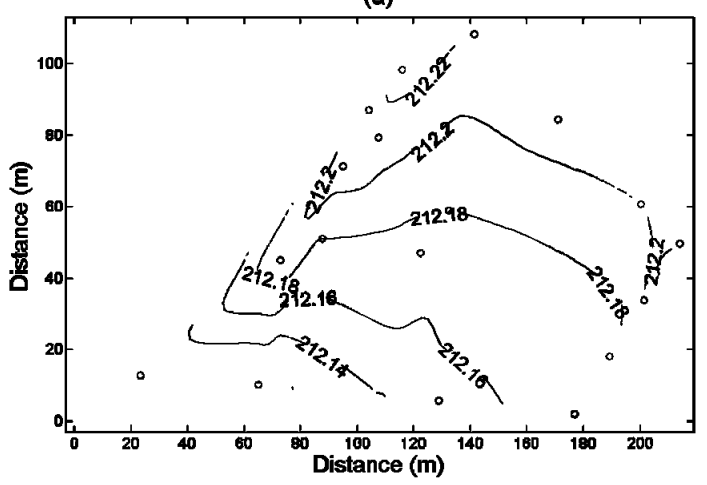

(b)

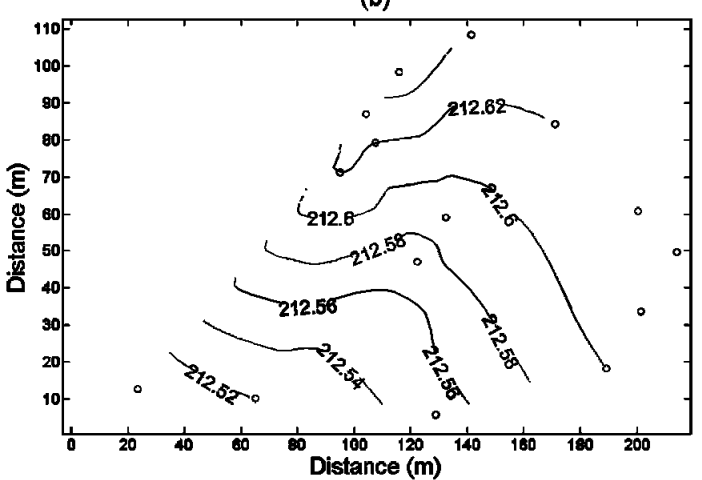

(c)

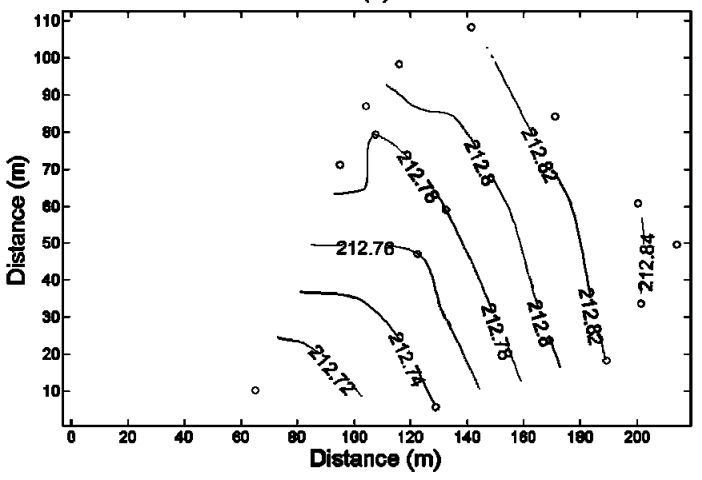

(d)

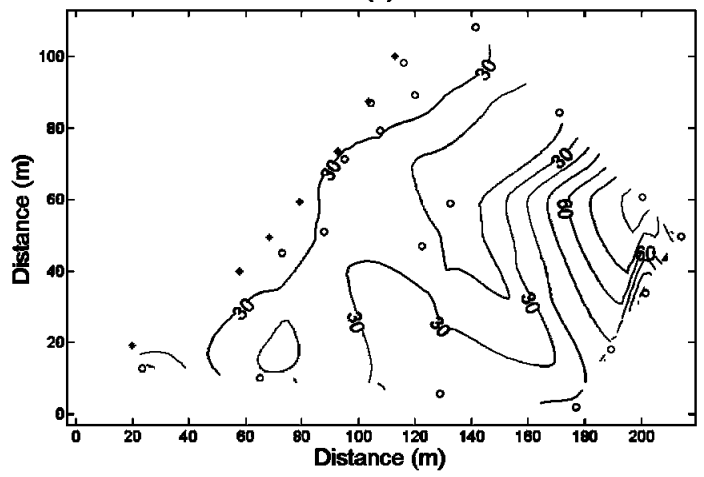

(e)

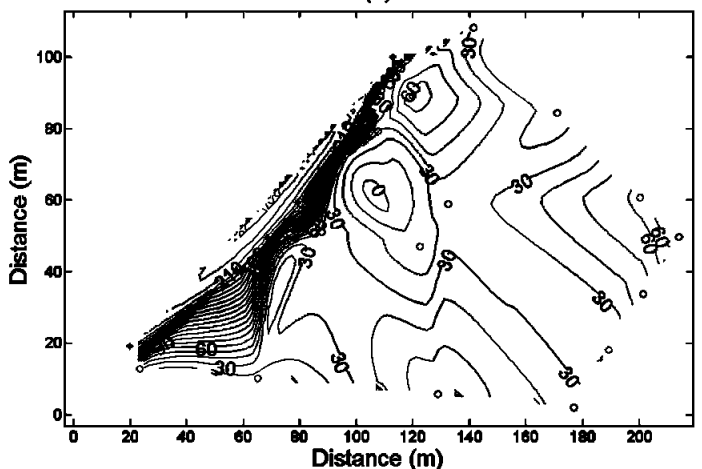

(f)

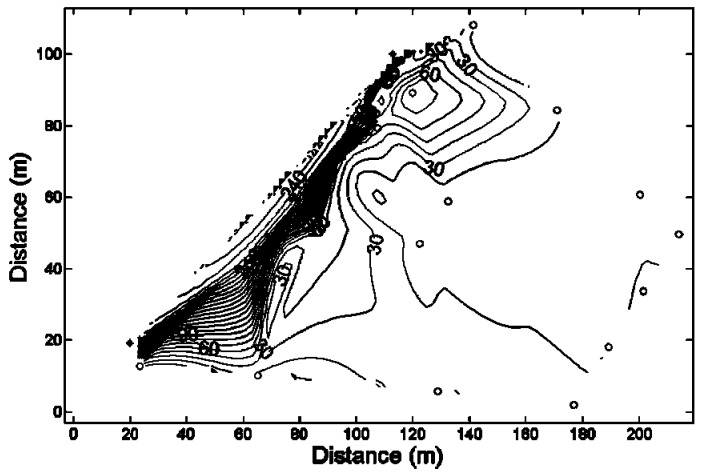

Figure 6. Water table ((a) (c)) and total phosphorus ((d) (f)) concentration ( $\mu \mathrm{g} / \mathrm{l}$ as $\mathrm{P})$ contour plots for the Barren Fork Creek site during the rising limb ((a) (d)) and the recession limb ((b) (e)) of March 23, 2010 high-flow event, and the recession limb ((c) (f)) of March 25, 20I0 high-flow event. Interpolations are based on measured data from wells (circles) and the stream (stars). See Table I and Figure 3 for more information on hydrologic conditions at the time of sampling. The loss of observation wells (c) is due to rapid streambank erosion rates (Midgley et al., 20II).

land runoff) infiltration, and existing $\mathrm{P}$ in upgradient groundwater. The water table elevation data (Figures 4-8) suggest that the source of P was primarily P-laden stream water entering the alluvial aquifer. Background concentrations in the aquifer during baseflow conditions (less than $0.06 \mathrm{mg} / \mathrm{l}$, Figures 4(d) and 7(e)) were low compared to the high total $\mathrm{P}$ concentrations observed during high-flow events. Owing to the low-intensity agricultural practices at each site, the topsoil was not expected to be a significant source of $\mathrm{P}$ to the groundwater. While the equilibrium $\mathrm{P}$ concentrations (based on STP data) for the top $15 \mathrm{~cm}$ of soil was likely higher than measured groundwater $\mathrm{P}$ concentrations, subsequent layers of loam were expected to have ample sorption sites available to remove $\mathrm{P}$ before leachate entered the aquifer. The timing of increases in ground- water $\mathrm{P}$ concentrations, which matched times of rising streamflow instead of times of rainfall, also indicated that any increases in P from leaching was insignificant.

To determine whether $\mathrm{P}$ concentrations in the observation wells varied with depth at the Barren Fork Creek site, low-flow sampling using a peristaltic pump was used on March 23, 2010, to collect samples at both the top of the water table (i.e. upper $10 \mathrm{~cm}$ ) and from $2.0 \mathrm{~m}$ below the water table. In most wells, $\mathrm{P}$ concentrations were similar at both depths. However, in well 28 (at point $(180 \mathrm{~m}, 0 \mathrm{~m})$ in Figure 6(e)), the 2-m sample had a P concentration of $0.19 \mathrm{mg} / 1$ (compared to $0.04 \mathrm{mg} / 1$ at the top of the water table), which approached the level of $\mathrm{P}$ in the stream. These concentrations suggested that this PFP was at a particular elevation, near the bottom of the alluvium. The high concentrations in well 28 


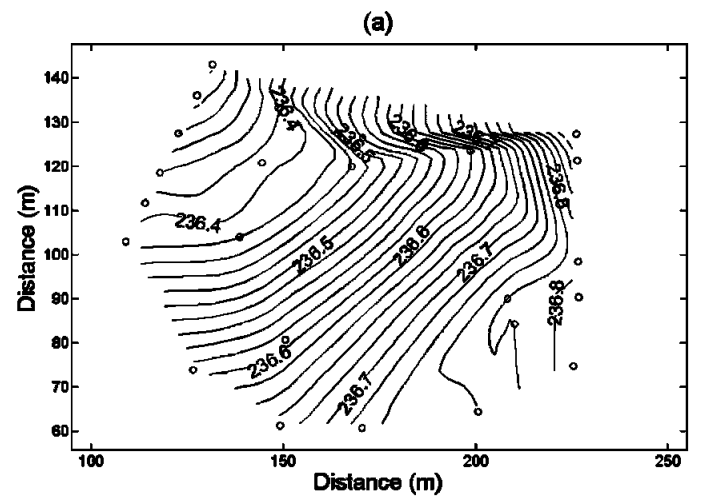

(b)

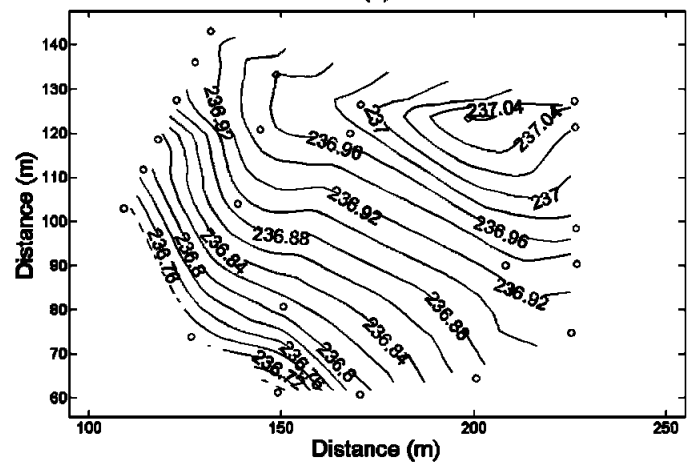

(c)

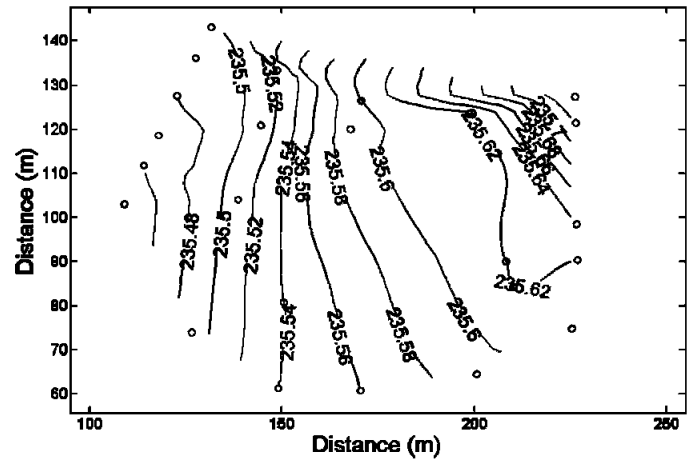

(d)

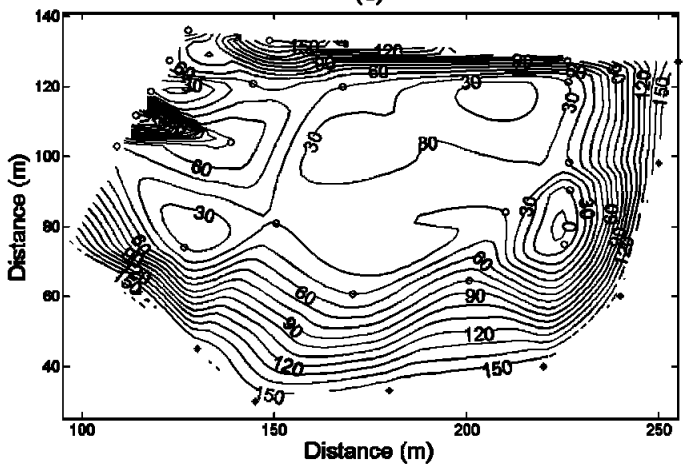

(e)

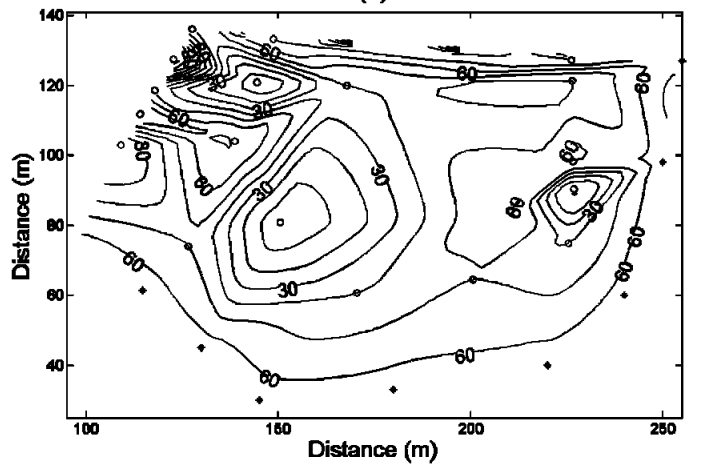

Figure 7. Water table ((a) (c)) and total phosphorus ((d) (e)) concentration ( $\mu \mathrm{g} / \mathrm{I}$ as P) contour plots for the Honey Creek site during the rising limb (a), recession limb ((b) (d)) and baseflow ((c) (e)) of October 9, 2009 high-flow event. Interpolations are based on measured data from wells (circles) and the stream (stars). See Table I and Figure 3 for more information on hydrologic conditions at the time of sampling.

may have been due to P-laden run-on infiltration (upland runoff has been observed cascading over the bluff in that area). However, the increasing $\mathrm{P}$ concentration with depth indicates lateral preferential transport from the stream instead of downward transport from the soil surface. Future work needs to address the three-dimensional nature of subsurface $\mathrm{P}$ transport.

Suspended colloids and sediment often possess particulate P; therefore, high total $\mathrm{P}$ concentrations tended to correspond with samples that were visibly cloudy. Differences between total dissolved $\mathrm{P}$ and dissolved reactive $\mathrm{P}$ were negligible, indicating that organic $\mathrm{P}$, if present, was only a minimal portion of the dissolved P. Particulate $\mathrm{P}$ (defined in this research as $\mathrm{P}$ attached to particulates greater than $0.45 \mu \mathrm{m})$ was calculated as the difference between total $\mathrm{P}$ (unfiltered) and dissolved reactive $\mathrm{P}$ (filtered). Using dissolved reactive $\mathrm{P}$ instead of total dissolved P (measured with the ICP) was justified due to negligible amount of dissolved organic P. Percent particulate $\mathrm{P}$ was calculated as the ratio of the particulate $\mathrm{P}$ to total $\mathrm{P}$, and ranged in the groundwater from 0 to $100 \%$, with means from 30 to $55 \%$ (Table I). Owing to the shallow depth of water in a few of the wells (wells further from the creek) at the Honey Creek site, the cloudiness in some samples may have been due to agitated sediment from the bottom of the well. However, even the deep wells (wells closer to the creek) at Honey Creek occasionally yielded cloudy samples from the top of the water table (e.g. well W at point $(160 \mathrm{~m}, 60 \mathrm{~m})$ in Figure 8(d) (f)) indicating colloidal transport of $\mathrm{P}$ in the groundwater.

Groundwater total P concentrations were also summarized by the median and interquartile range (Table I). A general linear model was performed on total $\mathrm{P}$ data for wells that were placed in subsoils with electrical resistivity data available (Figure 1). Differences between high resistivity and low resistivity wells were statisti- 
(a)

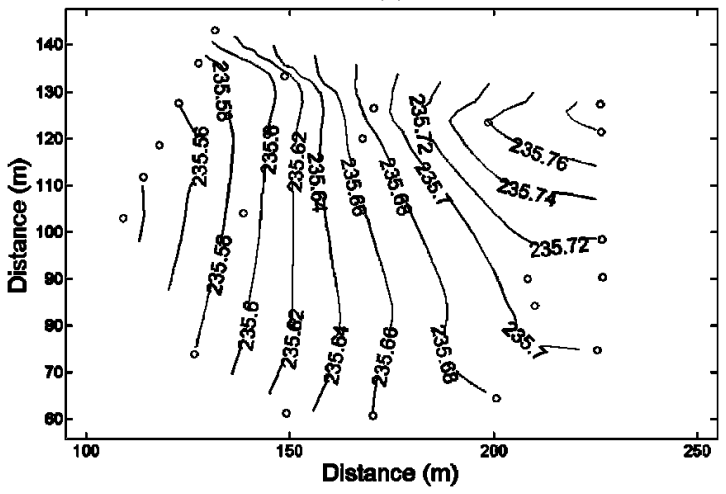

(b)

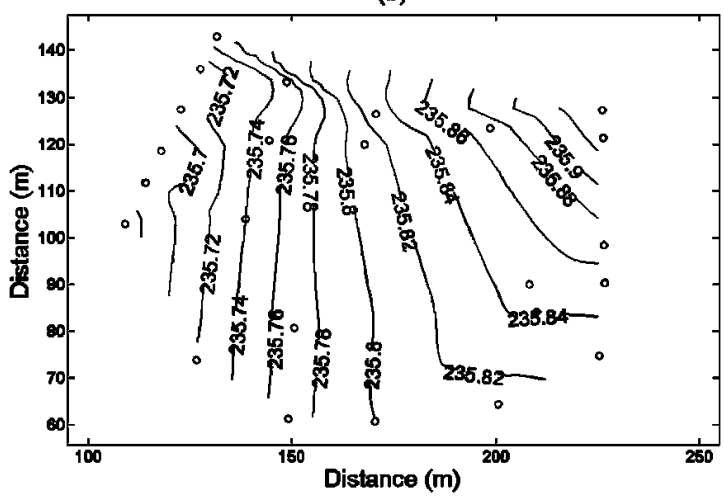

(c)

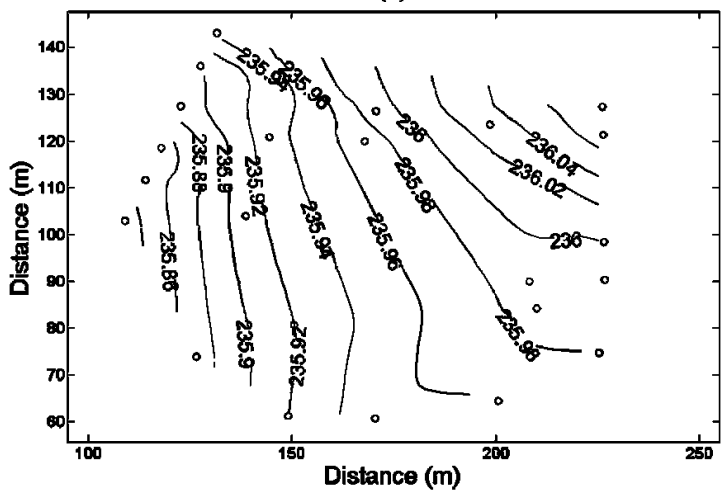

(d)

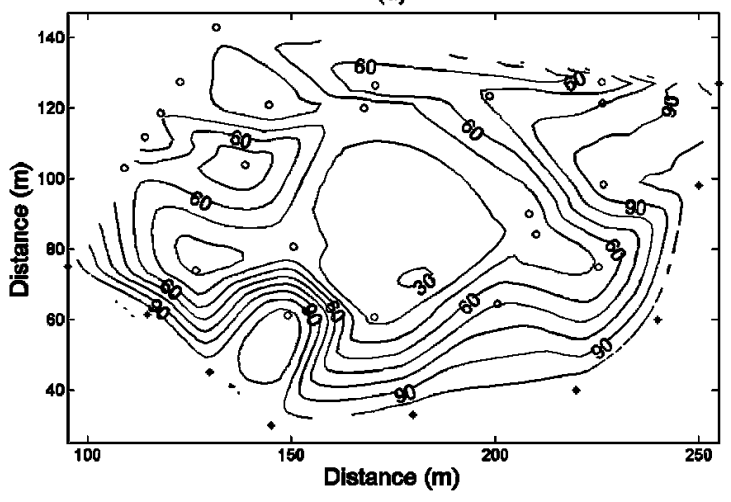

(e)

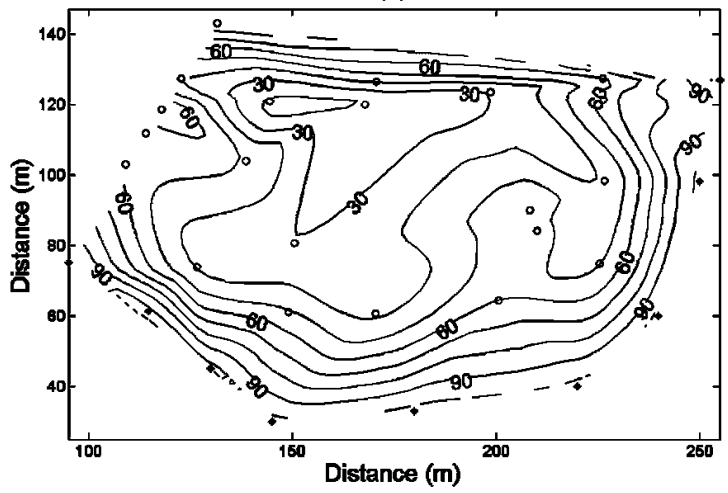

(f)

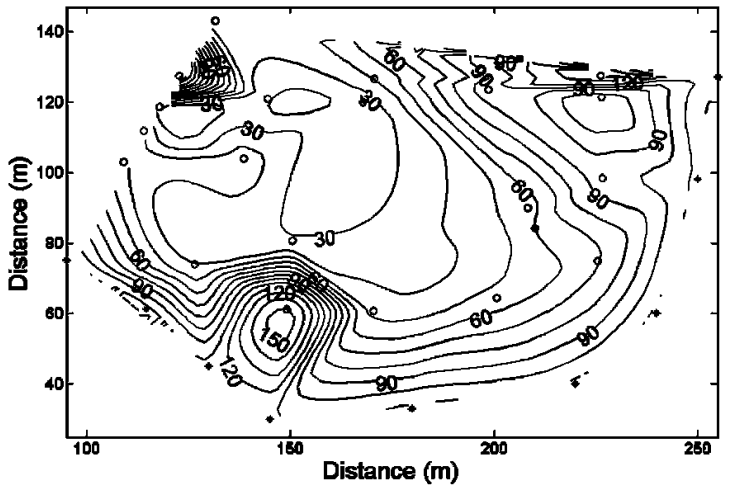

Figure 8. Water table ((a) (c)) and total phosphorus ((d) (f)) concentration ( $\mu \mathrm{g} / \mathrm{l}$ as $\mathrm{P})$ contour plots for the Honey Creek site during the rising limb ((a) (d)) and peak ((b) (e)) of March 23, 2010 high-flow event, and the recession limb ((c) (f)) of March 25, 2010 high-flow event. Interpolations are based on measured data from wells (circles) and the stream (stars). See Table I and Figure 3 for more information on hydrologic conditions at the time of sampling.

cally significant $(\alpha=0.05)$ at the Barren Fork Creek site (Table II). While not all PFPs transmitted high levels of $\mathrm{P}$, enough of them were hydraulically activated (water table above the elevation of the PFP) and connected to a source of $\mathrm{P}$ to result in a significant correlation between high resistivity and $\mathrm{P}$ transport. In this case, the source of $\mathrm{P}$ was P-rich stream water infiltrating the groundwater system. A source of error in the correlation could be imperfect identification of high hydraulic conductivity zones with the electrical resistivity data. The general linear model was also used to compare differences between wells close to the stream and wells far from the stream. The distance from the stream was a statistically significant variable $(\alpha=0.05)$ in two of the four datasets. This was consistent with the observation of $\mathrm{P}$ generally moving into the aquifer but with the movement of the plume being retarded due to sorption and dilution.

\section{Research implications}

As discussed by Packman and Bencala (2000), the surface and subsurface hydrological interactions in these alluvial floodplains can be viewed from two different perspectives. The first is viewing the interaction from the stream. From this viewpoint, the interaction is commonly idealized using a transient storage model that simulates hyporheic storage in an aggregate fashion as a well mixed but immobile system (Bencala and Walters, 1983). The groundwater flow and transport results in this research demonstrate exchange with the more 
Table II. Comparison of total phosphorus concentrations between wells close to and far from the stream and between high and lowresistivity observation wells. Probability $(p)$ is from a general linear model with $p<0.05$ being significant.

\begin{tabular}{lccc}
\hline Site & Year & \multicolumn{2}{c}{ Probability } \\
\cline { 3 - 4 } & & $\begin{array}{c}\text { Distance from } \\
\text { stream }\end{array}$ & $\begin{array}{l}\text { Electrical } \\
\text { resistivity }\end{array}$ \\
\hline Barren Fork Creek & 2010 & 0.03 & $<0.01$ \\
Barren Fork Creek & 2009 & 0.19 & $<0.01$ \\
Honey Creek & 2010 & $<0.01$ & 0.12 \\
Honey Creek & 2009 & 0.38 & 0.29 \\
\hline
\end{tabular}

extensive alluvium that would not be accounted for in near-streambed models. The presence of large-scale transient storage at high stream stage may have a direct impact on the transport of in-stream contaminant loads as the stream water interacts with the alluvial groundwater in floodplains throughout the watershed. Future work should be devoted to creating models capable of handling both the near-streambed and larger-scale transient storage to quantify implications of this larger-scale exchange on solute and contaminant transport in stream systems during both baseflow and high-flow conditions.

The second perspective is viewing the surface-subsurface interaction from the subsurface, which considers hyporheic exchange as the mixing of stream-derived and aquifer-derived water. This perspective relies heavily on the use of numerical groundwater flow models to describe reach-scale groundwater flow pathways (Packman and Bencala, 2000; Poole et al., 2006). Particle tracking models may be used to determine the extent of penetration of stream-derived water into the aquifer (Wroblicky et al., 1998). The stream is commonly idealized as a boundary that derives subsurface flow. The most sensitive parameter in groundwater flow models and the subject of most calibration effort is the aquifer hydraulic conductivity. The flow and transport results from the two floodplain studies reported in this research indicate the necessity of considering horizontal zones of aquifer heterogeneity and anisotropy within alluvial floodplains to adequately simulate larger-scale transient storage over a range of water table elevations. Heterogeneity has been modeled by assuming a distribution of hydraulic conductivity and that the distribution is randomly distributed in space (Gotovac et al., 2009). However, the non-random nature of the heterogeneity has been confirmed by variograms performed on hydraulic conductivity data in previous research at these alluvial sites (Miller et al., 2010). Higher electrical resistivity areas were hypothesized to be buried gravel bars, resulting in long, continuous zones of high conductivity (Heeren et al., 2010). Also, groundwater heads measured for flow calibration should be measured during both baseflow and high stream-stage events when the zones activate. It is important to appropriately identify potential PFPs prior to installation of observation wells for monitoring groundwater levels.

Owing to their close proximity and connectedness to streams, agricultural areas of gravelly floodplains may need to be managed differently than those of upland areas. While surface runoff is considered to be the primary transport mechanism for $\mathrm{P}$, subsurface transport through coarse subsoil to gravel bed streams would be a source of $\mathrm{P}$ not alleviated by current conservation practices (e.g. riparian buffers) aimed at surface runoff P loads. Though a highly sorbing contaminant, this research shows $\mathrm{P}$ being rapidly transported through coarse gravel subsoils. In these well managed sites, $\mathrm{P}$ leaching from the topsoil was not a significant source of $\mathrm{P}$ to the groundwater; therefore improvements in land management would likely have a minimal effect on subsurface $\mathrm{P}$ transport. However, intense agricultural management makes up a significant portion of the land-use in the Ozark ecoregion due to the presence of a poultry industry, and $\mathrm{P}$ leaching may be a significant source of $\mathrm{P}$ to the groundwater at these sites due to high STP levels throughout the soil profile. Also, the depth of the loam soil layer, which provides an opportunity for leachate to be filtered before reaching the gravel, ranges from 1 to $300 \mathrm{~cm}$ in the Oklahoma Ozark floodplains, and generally increases with increasing stream order. At one site in Pumpkin Hollow north of Tahlequah, OK, the loam is less than $2 \mathrm{~cm}$, and would provide only minimal $\mathrm{P}$ attenuation before runoff enters the alluvial aquifer. Ongoing research aims to quantify $\mathrm{P}$ leaching through loam soils of various depths. If $\mathrm{P}$ is found to leach through loam soil and to rapidly travel through gravel aquifers to streams, then new best management practices should be developed to halt or prevent the buildup of high STP levels in gravelly floodplains.

\section{Conclusions}

This research demonstrated significant interaction of both water and $\mathrm{P}$ between the stream and the aquifer. The coarse gravel aquifer acted as a transient storage zone, allowing large volumes of P-laden stream water to quickly enter the groundwater system during high-flow events and to subsequently exfiltrate to the stream during baseflow conditions. Future work should be devoted to creating models capable of handling both the nearstreambed and larger-scale transient storage to quantify implications of this larger-scale exchange on solute and contaminant transport in stream systems during both baseflow and high-flow conditions.

Particulate $\mathrm{P}$ was a significant portion of total $\mathrm{P}$ in these coarse gravel aquifers. Stage-dependent preferential flow pathways appeared to transport water and $\mathrm{P}$ rapidly from the stream through the groundwater system, with some groundwater having total P concentrations that mimicked stream concentrations. However, the impact of specific preferential flow pathways on $\mathrm{P}$ transport was not explicit due to the low spatial and time resolution of P samples throughout the saturated aquifer material. Future work should include a well controlled tracer study examining the impacts of preferential pathways on flow and transport. Additionally, more work needs to be done to characterize subsurface P transport when leaching from the topsoil is a significant source. 
Acknowledgments - This material is based upon work supported by the Oklahoma Conservation Commission with a U.S. Environmental Protection Agency Region VI 319 Grant. The authors acknowledge Mr Dan Butler and Mr Bill Berry for providing access to the alluvial floodplain properties. Dr Halihan has a managed conflict of interest with Oklahoma State University regarding the use of ERI developments.

\section{References}

Addiscott TM, Brockie D, Catt JA, Christian DG, Harris GL, Howse KR, Mirza NA, Pepper TJ. 2000. Phosphate losses through field drains in a heavy cultivated soil. Journal of Environmental Quality 29: 522-532. doi:10.2134/ jeq2000.00472425002900020021x

Amoros C, Bornette G. 2002. Connectivity and biocomplexity in waterbodies of riverine floodplains. Freshwater Biology 47: 761-776. doi: 10.1046/j.1365- 2427.2002.00905.x.

Andrews WJ, Becker MF, Smith SJ, Tortorelli RL. 2009. Summary of Surface-Water Quality Data from the Illinois River Basin in Northeast Oklahoma, 1970-2007 . Scientific Investigations Report 2009-5182. U.S. Geological Survey: Reston, VA.

Bencala KE, Walters RA. 1983. Simulation of solute transport in a mountain pool-and-riffle stream: A transient storage zone model. Water Resources Research 19: 718-724. doi:10.1029/WR019i003p00718.

Broberg O, Persson G. 1988. Particulate and dissolved phosphorus forms in freshwater: Composition and analysis. Hydrobiologia 170: 61-90.

Carlyle GC, Hill AR. 2001. Groundwater phosphate dynamics in a river riparian zone: Effects of hydrologic flow paths, lithology, and redox chemistry. Journal of Hydrology 247: 151-168. doi:10.1016/S0022- 1694(01)00375-4.

Cooper AB, Smith CM, Smith MJ. 1995. Effects of riparian set-aside on soil characteristics in an agricultural landscape: Implications for nutrient transport and retention. Agriculture, Ecosystems and Environment 55: 61-67. doi:10.1016/0167-8809(95)00605-R.

Cressie N. 1991. Statistics for Spatial Data. John Wiley and Sons: New York, NY; 900.

D'Angelo DJ, Webster JR, Gregory SV, Meyer JL. 1993. Transient storage in Appalachian and Cascade mountain streams as related to hydraulic characteristics. Journal of the North American Benthological Society 12: 223-235.

Daniel TC, Sharpley AN, Lemunyon JL. 1998. Agricultural phosphorus and eutrophication: A symposium overview. Journal of Environmental Quality 27: 251-257. doi:10.2134/ jeq1998.0047242500270002- 0002x.

Davis RK, Hamilton S, Van Brahana J. 2005. Escherichia coli survival in mantled karst springs and streams, Northwest Arkansas Ozarks, USA. Journal of the American Water Resources Association 41: 1279-1287. doi:10.1111/j.1752-1688.2005. tb03800.x.

de Jonge LW, Kjaergaard C, Moldrup P. 2004. Colloids and colloid-facilitated transport of contaminants in soils: An introduction. Vadose Zone Journal 3: 321-325. doi:10.2136/ vzj2004.0321.

Djodjic F, Katarina B, Bergstrom L. 2004. Phosphorus leaching in relation to soil type and soil phosphorus content. Journal of Environmental Quality 33: 678-684. doi:10.2134/ jeq2004.0678.
Fuchs JW, Fox GA, Storm DE, Penn CJ, Brown GO. 2009. Subsurface transport of phosphorus in riparian floodplains: Influence of preferential flow paths. Journal of Environmental Quality 38: 473-484. doi:10.2134/jeq2008.0201.

Gachter R, Ngatiah JM, Stamm C. 1998. Transport of phosphate from soil to surface waters by preferential flow. Environmental Science and Technology 32: 1865-1869. doi:10.1021/es9707825.

Gotovac H, Cvetkovic V, Andricevic R. 2009. Flow and travel time statistics in highly heterogeneous porous media. Water Resources Research 45: W07402. doi:1029/2008WR007168.

Halihan T, Paxton S, Graham I, Fenstemaker T, Riley, M. 2005. Post-remediation evaluation of a LNAPL site using electrical resistivity imaging. Journal of Environmental Modeling 7: 283-287. doi: 10.1039/b416484a.

Hart DR, Mulholland PJ, Marzolf ER, Deangelis DL, Hendricks SP. 1999. Relationships between hydraulic parameters in a small stream under varying flow and seasonal conditions. Hydrological Processes 13: 1497-1510.

Harvey JW, Wagner BJ, Bencala KE. 1996. Evaluating the reliability of the stream tracer approach to characterize stream-subsurface water exchange. Water Resources Research 32: 2441-2451. doi: 10.1029/96WR01268.

Haygarth PM, Warwick MS, House WA. 1997. Size distribution of colloidal molybdate reactive phosphorus in river waters and soil solution. Water Research 31: 439-448. doi:10.1016/S0043- 1354(96)00270-9.

Heathwaite AL, Dils RM. 2000. Characterizing phosphorus loss in surface and subsurface hydrological pathways. Science of the Total Environment 251: 523-538.

Heeren DM, Miller RB, Fox GA, Storm DE, Penn CJ, Halihan T. 2010. Preferential flow path effects on subsurface contaminant transport in alluvial floodplains. Transactions of the ASABE 53: 127-136.

Hively WD, Gerard-Marchant P, Steenhuis TS. 2006. Distributed hydrological modeling of total dissolved phosphorus transport in an agricultural landscape, part II: Dissolved phosphorus transport. Hydrology and Earth System Sciences 10: 263-276. doi:10.5194/hess-10-263-2006.

Kleinman PJA, Needelman BA, Sharpley AN, McDowell RW. 2004. Using soil phosphorus profile data to assess phosphorus leaching potential in manured soils. Soil Science Society of America Journal 67: 215-224. doi:10.2136/ sssaj2003.0215.

Lacas J-G, Voltz M, Gouy V, Carluer N, Gril J-J. 2005. Using grassed strips to limit pesticide transfer to surface water: A review. Agronomy for Sustainable Development 25: 253-266. doi: 10.1051/agro:2005001.

Malard F, Tockner K, Dole-Oliver MJ, Ward JV. 2002. A landscape perspective of surface-subsurface hydrological exchanges in river corridors. Freshwater Biology 47: 621-640. doi: 10.1046/j.1365- 2427. 2002.00906.x.

Midgley TL, Fox GA, Heeren DM. 2011. Evaluation of the Bank Stability and Toe Erosion Model (BSTEM) for predicting lateral streambank retreat in Ozark streams. Proceedings of the American Society of Civil Engineers Environmental Water Resources Institute Annual Meeting, Palm Springs, CA (CD-ROM).

Miller RB, Heeren DM, Fox GA, Storm DE, Halihan T, Mittelstet AR. 2010. Geophysical mapping of preferential flow paths across multiple floodplains. ASABE Paper No. 
1008730. American Society of Agricultural and Biological Engineers: St. Joseph, Mich.

Miller RB, Heeren DM, Fox GA, Storm DE, Halihan T. 2011. Design and application of a direct-push vadose zone gravel permeameter. Groundwater (in press). doi: 10.1111/j.1745- 6584.2010.00796.x.

Morrice JA, Valett HM, Dahm CN, Campana ME. 1997. Alluvial characteristics, groundwater-surface water exchange and hydrologic retention in headwater streams. Hydrological Processes 11: 253-267.

Murphy J, Riley JP. 1962. A modified single solution method for the determination of phosphate in natural waters. Analytica Chimica Acta 27: 31-36.

Naiman RJ, Decamps H, McClain ME. 2005. Catchments and the physical template. In Riparia: Ecology, Conservation, and Management of Streamside Communities Elsevier Academic Press: Boston, MA; 19-48.

Neill H, Gutierrez M, Aley T. 2003. Influences of agricultural practices on water quality of Tumbling Creek cave stream in Taney County, Missouri. Environmental Geology 45: 550559. doi: 10.1007/s00254- 003-0910-2.

Nelson NO, Parsons JE, Mikkelson RL. 2005. Field-scale evaluation of phosphorus leaching in acid sandy soils receiving swine waste. Journal of Environmental Quality 34: 20242035. doi: 10.2134 /jeq2004.0445.

Oklahoma Water Resources Board (OWRB). 2010. Oklahoma's Water Quality Standards, 785: 45, http:/ / www.owrb. ok.gov/util/rules/pdfrul/RulesCurrent2010/Ch45.pdf

Packman AI, Bencala KE. 2000. Modeling surface-subsurface hydrological interactions. In Streams and Ground Waters, Jones JB, Mulholland PJ (eds.). Academic Press: San Diego, CA; $46-77$.

Pellerin L. 2002. Applications of electrical and electromagnetic methods for environmental and geotechnical investigations. Surveys in Geophysics 23: 101-132. doi: 10.1023/ A:1015044200567.

Poole GC, Naiman RJ, Pastor J, Stanford JA. 1997. Uses and limitations of ground penetrating RADAR in two riparian systems. In Groundwater/Surface Water Ecotones: Biological and Hydrological Interactions and Management Options, Gibert J, Mathieu J, Fournier F (eds.). Cambridge University Press: Cambridge, England; 140-148.

Poole GC, Stanford JA, Frissell CA, Running SW. 2002. Three-dimensional mapping of geomorphic controls on flood-plain hydrology and connectivity from aerial photos. Geomorphology 48(4): 329-347. doi:10.1016/ S0169-555X(02)00078-8.

Poole GC, Standford JA, Running SW, Frissell CA. 2006. Multiscale geomorphic drivers of groundwater flow paths: subsurface hydrologic dynamics and hyporheic habitat diversity. Journal of the North American Benthological Society 25: 288-303.

Pote DH, Daniel TC, DeLaune PB. 2009. Total phosphorus and total dissolved phosphorus in water samples. In Methods of Phosphorus Analysis for Soils, Sediments, Residuals, and Waters Kovar JL, Pierzynski GM, (eds.). Virginia Tech University: Blacksburg, VA; pp. 113-114.
Robinson DA, Binley A, Crook N, Day-Lewis FD, Ferré TPA, Grauch VJS, Knight R, Knoll M, Lakshmi V, Miller R, Nyquist J, Pellerin L, Singha K, Slater L. 2008. Advancing process-based watershed hydrological research using nearsurface geophysics: A vision for, and review of, electrical and magnetic geophysical methods. Hydrological Processes 22: 3604-3635.

Sauer TJ, Logsdon SD. 2002. Hydraulic and physical properties of stony soils in a small watershed. Soil Science Society of America Journal 66: 1947-1956. doi: 10.2136/sssaj2002.1947.

Sims JT, Simard RR, Joern BC. 1998. Phosphorus loss in agricultural drainage: Historical perspective and current research. Journal of Environmental Quality 27: 277-293.

Stamm C, Flühler H, Gächter R, Leuenberger J, Wunderli H. 1998. Preferential transport of phosphorus in drained grassland soils. Journal of Environmental Quality 27: 515-522.

Stanford JA, Ward JV. 1992. Management of aquatic resources in large catchments: Recognizing interaction between ecosystem connectivity and environmental disturbance. In Watershed Management, Naiman RJ (ed). Springer-Verlag: New York, NY; 91-124.

Stofleth JM, Shields Jr. FD, Fox GA. 2008. Hyporheic and total storage exchange in small sand-bed streams. Hydrological Processes 22: 1885-1894.

Thompson CA, McFarland AMS. 2010. Effects of surface and groundwater interactions on phosphorus transport within streambank sediments. Journal of Environmental Quality 39: 548-557. doi: 10.2134/jeq2009.0313.

Turner BL, Haygarth PM. 2000. Phosphorus forms and concentrations in leachate under four grassland soil types. Soil Science Society of America Journal 64: 1090-1099.

Vadas PA, Srinivasan MS, Kleinman PJA, Schmidt JP, Allen AL. 2007. Hydrology and groundwater nutrient concentrations in a ditch-drained agro-ecosystem. Journal of Soil and Water Conservation 62: 178-188.

Vanek V. 1993. Transport of groundwater-borne phosphorus to Lake Bysjon, South Sweden. Hydrobiologia 251: 211-216.

Worman A, Packman AI, Johansson H, Jonsson K. 2002. Effect of flow-induced exchange in hyporheic zones on longitudinal transport of solutes in streams and rivers. Water Resources Research 38(1): doi: 10.1029/2001WR000769.

Wroblicky GW, Campana ME, Valett HM, Dahm CN. 1998. Seasonal variation in surface-subsurface water exchange and lateral hyporheic area of two stream-aquifer systems. Water Resources Research 34: 317-328.

Zarnetske JP, Gooseff MN, Brosten TR, Bradford JH, McNamara JP, Bowden WB. 2007. Transient storage as a function of geomorphology, discharge, and permafrost active layer conditions in Arctic tundra streams. Water Resources Research 43: W07410. doi: 10.1029/2005WR004816. 